\title{
Yb-волоконные лазеры, излучающие в спектральном диапазоне около 0.98 мкм
}

\author{
С.С. Алешкина ${ }^{*}$, М.Е. Лихачев \\ Институт общей физики им. А.М. Прохорова РАН \\ Научный центр волоконной оптики им. Е.М. Дианова \\ *E-mail: svalesh@fo.gpi.ru
}

DOI: 10.31868/RFL2020.47-48

Интерес к Үb-волоконным одномодовым лазерам на 0.98 мкм в первую очередь обусловлен перспективами использования таких источников в качестве волоконных аналогов газовым лазерам на аргоне и криптоне (путем удвоения и учетверения длины волны излучения). Кроме того, Yb-лазеры на 0.98 мкм могут быть использованы в качестве источников одномодовой накачки Er- и Yb-лазеров и усилителей.

В то же время высокие пороги генерации (являющиеся следствием работы $\mathrm{Yb}$ по трехуровневой лазерной схеме), большая доля непоглощенной накачки (и, как следствие, низкая эффективность), обусловленная необходимостью сокращения длины активного световода для подавления генерации в спектральной области более 1 мкм, делают Yb-лазеры на основе стандартных волоконных световодов непривлекательными с практической точки зрения. Использование конструкций специальных волоконных световодов позволяет преодолеть эти ограничения и реализовать источники не только непрерывного, но и импульсного излучения.

Так, к настоящему моменту существует несколько подходов увеличения эффективности Yb-лазеров на 0.98 мкм. Первый из них связан с увеличением области легирования относительно области распространения излучения накачки. Частным случаем этого метода выступает использование схем с одномодовой накачкой по сердцевине [1-2]. Однако в силу отсутствия мощных коммерчески доступных одномодовых диодов накачки и в силу сложности реализации волоконных схем лазеров на длинах волн накачки этот подход не получил широкого распространения. Наилучшие результаты по генерации излучения на 0.98 мкм получены при использовании схем с многомодовой накачкой и световодов с двойной отражающей оболочкой, соответственно. С целью увеличения скорости поглощения излучения накачки при сохранении одномодового режима распространения в световодах с двойной отражающей оболочкой применяются следующие методики: методика увеличения размера легированной $\mathrm{Yb}$ сердцевины и одновременное уменьшение апертуры сердцевины [3-6], методика использования конусных волоконных световодов [78], а так же методика уменьшения размера кварцевой оболочки [9]. Еще одним способом реализации мощных источников лазерного излучения на 0.98 мкм является применение в схеме лазера конструкции световода с избыточными потерями на длинах волн более 1 мкм. Так в [10] была предложена и реализована конструкция световода с фотонной запрещенной зоной, сердцевина которого обеспечивала эффективную локализацию моды на длине волны около 0.98 мкм и не обладала волноводными свойствами в спектральной области нежелательного излучения $\mathrm{Yb}$ (более 1 мкм).

Задача создания импульсных $\mathrm{Yb}$-лазеров накладывает дополнительные условия и ограничения для генерации излучения на 0.98 мкм. Сильная обратная связь ужесточает требования эффективности подавления излучения в области 
длин волн более 1 мкм и требования увеличения скорости поглощения накачки. Кроме того, использование в схемах световодов с увеличенным размером сердцевины приводит к невозможности реализации полностью волоконных схем лазера. В связи с этим недавно была разработана конструкция специального Ybволоконного световода с легированной оболочкой [11]. Сопоставимость волноводных параметров сердцевины и оболочки световода с параметрами коммерчески доступных волоконных световодов позволило впервые реализовать полностью волоконную РМ-схему Yb-лазера пикосекундной длительности [12], a так же полностью волоконную схему лазера, поставляющего импульсы, которые могут быть сжаты до фемтосекундной [13] длительности.

\section{Литература}

[1] M. Laroche, C. Bartolacci et.al, in Advances in Optical Materials, OSA Technical Digest (CD) (Optical Society of America, 2011), ATuB9 (2011)

[2] L.B. Fu, M. Ibsen et al, in IEEE Photonics Technology Letters 16(11), 2442-2444 (2004)

[3] S.S. Aleshkina, M.E. Likhachev et.al, Proc. SPIE 9728, 97281C(2016)

[4] J. Boullet, Y. Zaouter et.al, Opt. Exp. 16(22), 17891-17902 (2008)

[5] F. Röser, C. Jauregui et.al, Opt. Exp. 16(22), 17310-17318 (2008)

[6] N. Valero, C. Feral et.al, Opt. Lett. 45, 1495-1498 (2020)

[7] M. Leich, M. Jäger et.al, Laser Phys. Lett. 11(4), 045102 (2014)

[8] S.S. Aleshkina, A.E. Levchenko et al., in IEEE Photonics Technology Letters 30(1), 127-130 (2018)

[9] L. Kotov, V. Temyanko et.al, Opt. Lett, to be published

[10] W. Li, T. Matniyaz et.al, Opt. Express 27, 24972 (2019).

[11] S.S. Aleshkina, D.S. Lipatov et.al, Quantum Electron. 49, 919 (2019)

[12] S.S. Aleshkina, A. Fedotov et.al, Opt. Lett. 45, 2275-2278 (2020)

[13] S.S. Aleshkina, D.S. Lipatov et.al, in IEEE Photonics Technology Letters 32(13), 811-814 (2020) 